\title{
Information on sellers and buyers characteristics: added value to explain price formation at primary fish markets in managed French scallop fisheries
}

\author{
Lesur-Irichabeau Gabrielle ${ }^{1,2,{ }^{*}}$, Guyader Olivier ${ }^{1}$, Frésard Marjolaine ${ }^{3}$, Leroy C. ${ }^{4}$, Latouche K. ${ }^{4}$, \\ Le Grel L. ${ }^{5,6}$
}

${ }^{1}$ IFREMER, UMR AMURE, Unité d'Economie Maritime, BP 70, 29280 Plouzané, France

${ }^{2}$ Université de Bordeaux, GREThA, UMR CNRS 5113, avenue Léon Duguit, 33608 Pessac, France

${ }^{3}$ Université de Brest, UEB, UMR AMURE, 12 rue de Kergoat, CS 93837, 29238 Brest Cedex 3, France

${ }^{4}$ INRA, Centre de recherche Angers-Nantes, Unité LERECO, Rue de la Géraudière, BP 71627, 44316

Nantes Cedex 3, France

${ }^{5}$ FISH PASS, 3 rue des Grands Champs, Z.A. des 3 Prés, 35890 Laillé, France

${ }^{6}$ ONIRIS-NANTES, LARGECIA, BP 82225, 44322 Nantes Cedex 3, France

* Corresponding author : Gabrielle Lesur-Irichabeau, email address : gabrielle.lesur.irichabeau@ifremer.fr

\begin{abstract}
:
The aim of this article is to explore, through a hedonic approach, the factors that might explain the price variability for the French-managed fishery of scallop at primary fish markets. In addition to factors classically identified in the current literature like intrinsic product characteristics or markets situation, the characteristics of operators are tested. The relationships of loyalty between sellers and buyers, and market assiduity are notably considered.
\end{abstract}

Keywords : Buyer and seller characteristics, fisheries management, hedonic price, market behaviour, market structure, scallop, Q21, Q22, Q28, C10, L11 


\section{INTRODUCTION}

French market of Scallop (Pecten maximus) is a particular market in the sense that the supply is regulated by management systems that are designed to ensure the sustainability of the resource and therefore associated economic activity. These management systems have implications on market structure as much on supply as on demand with consequences on the price formation mechanisms in both the short and long term. (BjØrndal et al., 1992; McCay et al., 1995; Matulich et al., 1996; Helstad et al., 2005). These management systems impose production conditions making the products landed in a management area relatively homogeneous in appearance. This relative product homogeneity due to a production under the same conditions is however not translated into price homogeneity. This implies that more attention is needed to devote to other factors than the quality attributes of fish or market conditions in analysis of prices; in particular, it is needed to consider the characteristics of operators, their market behaviour and interpersonal relationships.

Many studies have set out to examine price formation mechanisms for sea products. Some have concentrated on estimating inverse demand functions (Barten and Bettendorf, 1989; Eales and Unnevehr, 1994; Matsuda, 2007) enabling estimation of how sensitive the relationship between price and quantities landed really is. Others have focused on showing the influence of various brands or ecolabels (Roheim et al., 2007; Roheim et al., 2011; Sogn-Grundvag et al., 2014), gear types (McConnell and Strand, 2000; Asche and Guillen, 2012; Sogn-Grundvag et al., 2013, 2014), geographical origins (Asche and Guillen, 2012; Guillen and Maynou, 2014) or other attributes of the fish such as size, weight, presentation, or even colour (Gates 1974; McConnell and Strand, 2000; Carroll et al., 2001; Asche and Guttormsen, 2001; Alfnes et al., 2006; Smith and Gopalakrishnan, 2010; Zimmermann and Heino, 2013; 
Dey et al., 2014; Sogn-Grundvag et al., 2014). Helstad et al. (2005) have chosen an approach that closely scrutinises the links between selling methods (auction or direct sales) and price. Others have focused on how the relationships between buyers and sellers have impacted prices (Kirman and Vriend, 2000; Gallegati et al., 2011; Vignes and Etienne, 2011; Cirillo et al., 2012; Fluvià et al., 2012) but this type of effect has never been included in hedonic models.

The scallop (Pecten maximus) fishery is one of the largest fisheries in France (Meunier et al., 2013). Existing management systems are based mainly on regulation of inputs, and are characterised by the granting of fishing licenses (numerus clausus), limitations on fishing effort, and a calendar governing the duration of the fishing season (Fifas et al., 2003; Alban and Boncoeur, 2008; OCDE, 2012). The scallop is a sedentary species, with stocks distributed throughout the English Channel. The fishery is made up accordingly of several sub-fisheries with differing management practices to take into account the particular ecological, biological and socio-economic characteristics encountered in each area (Fifas et al., 2003; Guyader et al., 2004; Binet, 2010; Guyader et al., 2013). These characteristics favour a relatively heterogeneous range of products landed in the various auction halls around the English Channel, with as many sub-markets as there are management system zones and relatively homogeneous products within the same sub-market.

The licensing system implies that fishers have very few opportunities to operate in different management areas (Arzel et al., 2005; Alban and Boncoeur, 2008). As a consequence most of the fishers tend to limit their fishing operation in only one management area. Inertia does not only concern fishers but also, to a certain extent, the buyers on primary fish markets. The latter rarely vary their sourcing and supply sites (Lesur-Irichabeau et al., 2014) despite the opening up of opportunities to buy on 
the various sub-markets thanks to the computerisation of auction halls and the introduction of remote buying systems (Guillotreau et al., 2006).

The objective of this article is to use a hedonic approach to explore those factors that are likely to explain the variability of the price of the scallop in a same management area, while giving equal consideration to characteristics such as the market, the products, their substitutability as a function of their origin, modalities and characteristics of the transactions. Particular attention is given to the influence of characteristics of the operators and their relationships at primary markets. Because we only study the transactions on the primary market, we assume that buyers are intermediaries acting in accordance with their knowledge of willingness to pay for the next buyers, whether intermediate or final consumers, given scallop characteristics.

\section{FRENCH SCALLOP FISHERIES}

The scallop (Pecten maximus) is the leading species landed in France (15.8 thousand tons) and ranks fourth in terms of value (€ 37.6 million) in 2012 . The 8 main fishing zones - referred to below as 'management areas' (MA) - are located in the French territorial waters, with the Saint Brieuc Bay (MA_3) and the Bay of the Seine (MA_6) accounting for $37 \%$ and $28 \%$ respectively of the total production in the English Channel (Fig. 1) ${ }^{1}$. The various sub-markets considered correspond to the different management areas. Prices differ from one management area to another, with a minimum average annual price of $2.1 € / \mathrm{kg}$ in MA_3 and a maximum of $3.9 € / \mathrm{kg}$ in MA_1.

\footnotetext{
${ }^{1}$ The other French fishing grounds located in the Bay of Biscay represent less than 4\% of the French production figure and are not considered in this study.
} 


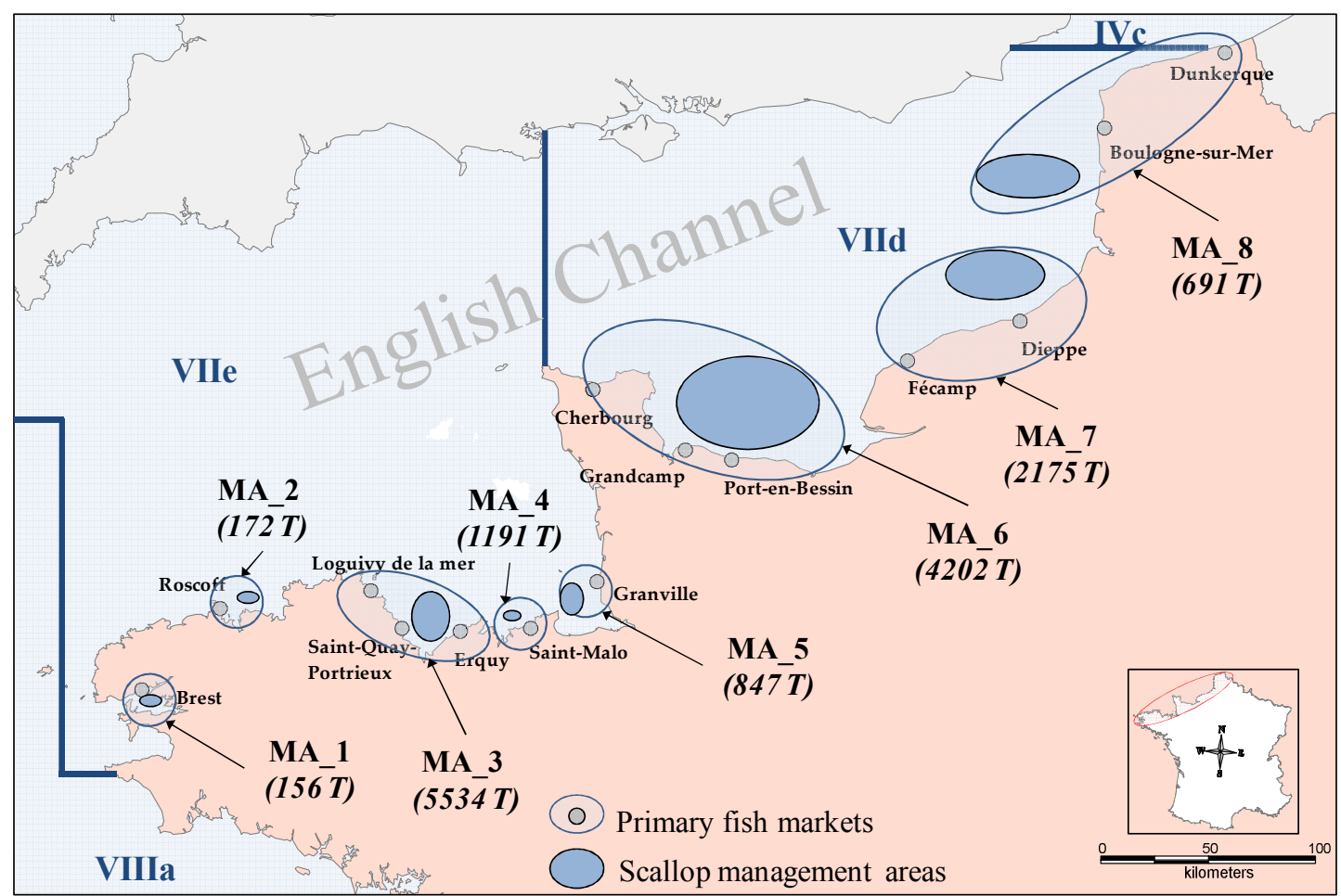

Source: Authors based on the map of French Scallop Fisheries (http://aquacultureaquablog.blogspot.fr) and IFREMER-SIH data.

Note: Data in brackets indicate the tonnage of scallops produced in each management area (MA) in 2012.

\section{Fig. 1. Scallop management areas and primary fish markets locations}

As each zone is managed independently of the others (Fifas et al. 2003), the structures of the fleets are heterogeneous. As the table 1 shows, the vessel length and engine power almost consistently increase from West to East across the Channel, with a minimum of $9.4 \mathrm{~m}(87 \mathrm{~kW})$ in zone MA_1 and a maximum of $16.7 \mathrm{~m} \mathrm{(312}$ $\mathrm{kW}$ ) in zone MA_8. As the number of authorised fishing days is also defined by the individual management system, each sub-market differs in terms of the number of days of activity (days with transactions) with a more sustained activity in the East than in the West. 
The number of buyers ${ }^{2}$ in primary fish market halls is relatively homogeneous between fishing grounds. As indicated in Table 1, the majority of fishing grounds are characterized by a predominance of fishmongers which are intermediary operators. They are key operators to the extent that they supply purchasing services for the major national retailers. These central purchasing services are responsible for centralizing purchasing operations so they can be subsequently redistributed over the national territory. Whatever the fishing ground, part of the production figure is bought by retail operators, mainly fish merchants, for resale to the end consumer. Some buyers may, in certain instances, be import and/or export operators.

Table 1. Management areas characteristics in 2012

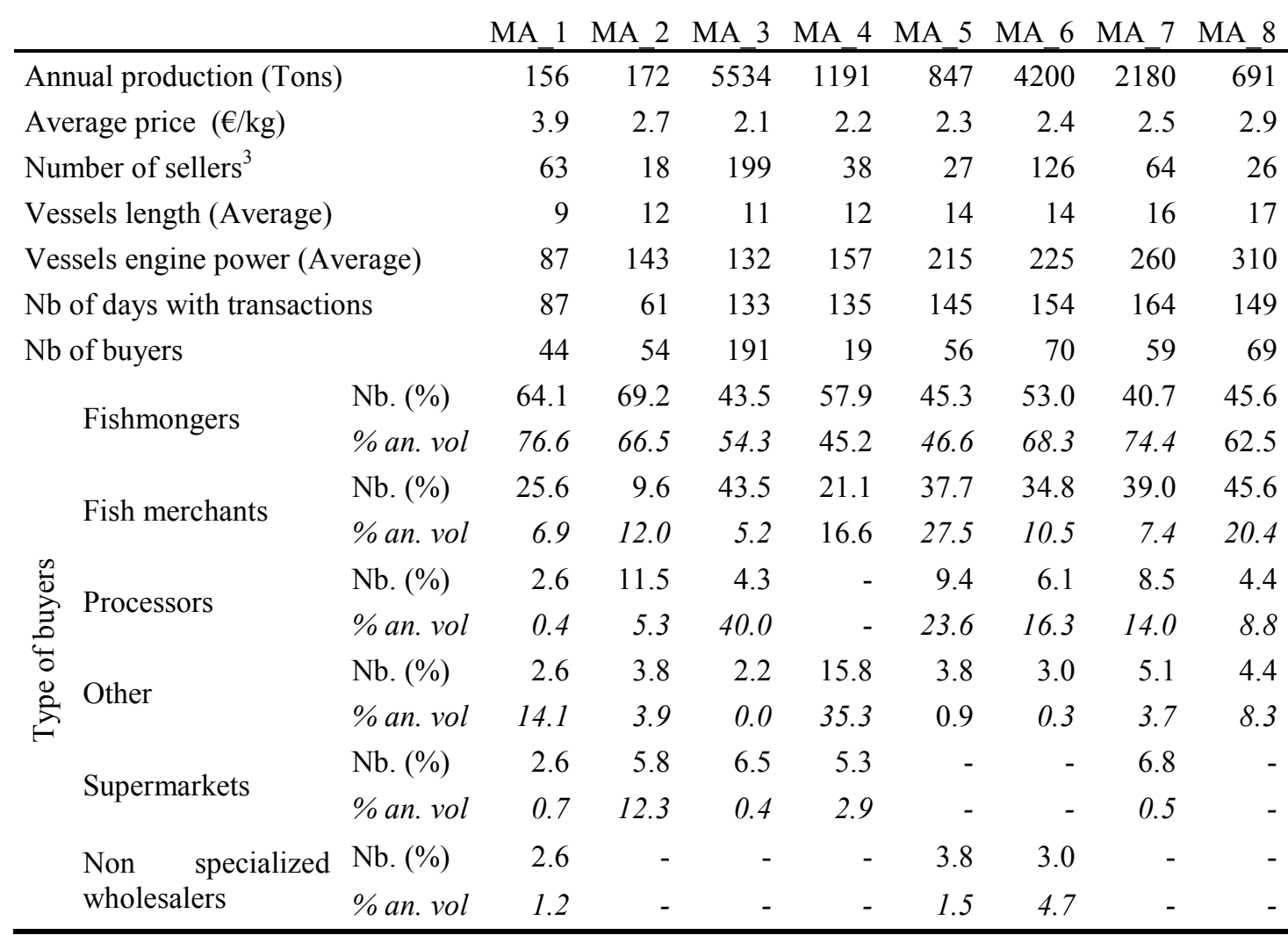

\footnotetext{
${ }^{2}$ The number of buyers in the management area 3 is relatively large compared to other management areas due to the obligation for fishers to sell their entire production at auction hall. Fishers have to buy their own production if they want to sell it themselves.

${ }^{3} \mathrm{We}$ refer also to the vessel or to the fisher to designate 'seller'.
} 
All buyers at the primary fish market are intermediaries but not in the same way. Fish merchants are, for example, intermediaries between fisher and the end consumer. Their marketing zone is, usually at any rate, in the vicinity of the fishing grounds themselves, in the framework of short circuits. Fish mongers are larger scale operators, notably with an intermediary role for central purchasing services and supermarkets distribution networks when the latter are not themselves buyers in the primary fish market. Processors only transform the product, mainly into for scallop frozen meat.

\section{METHOD AND DATA}

\section{Hedonic price function and marginal effects}

A hedonic price function is estimated for each of the eight management areas under consideration. The functional form selected differs depending on the fishing ground, but the general form is the following:

$$
\ln Y=\alpha+\beta \ln X+\delta X^{\prime}+\phi Z+\varepsilon
$$

where $X$ and $X^{\prime}$ are continuous variables which, depending on the model, are in logarithmic or normal format and $Z$, are the dummy variables. Each model is estimated using the same set of explanatory variables. From estimated coefficients, it will be possible to calculate the marginal effects that enable us to quantify the sensitivity of the price to a variation in a component of the latter. The calculation of these marginal effects differs according to the nature of the explanatory variables. Table 2 below describes the rules for interpreting by type of variable. 
Table 2. Interpretation rules for estimated coefficients (Terra, 2005)

\begin{tabular}{lll}
\hline Type & Calculation & Interpretation \\
\hline Log & $\hat{\beta}_{k}$ & $\begin{array}{l}\text { A } 1 \% \text { increase in the explanatory variable corresponds to an } \\
\text { increase of } \hat{\beta}_{k} \% \text { of the sale price per kilo }\end{array}$ \\
Norm $\quad \hat{\beta}_{k} \times 100$ & $\begin{array}{l}\text { A one-unit increase in the explanatory variable corresponds to a } \\
\text { variation of } 100 \times \hat{\beta}_{k} \% \text { of the sale price per kilo }\end{array}$ \\
Dum $\quad g=100\left(e^{\hat{\beta}_{k}}-1\right)$ & $\begin{array}{l}\text { The percentage impact of modality taking the value } 1 \text { of the } \\
\text { explanatory variable on the sale price per kilo is equal to } g\end{array}$ \\
\hline
\end{tabular}

Data

The database used includes 32,166 market transactions for scallops in the year 2012, extracted from sales data. The sales data deliver information about sales of fishery products, mainly in the fish auction halls. They are recorded by the Inter-Auction Network (RIC) ${ }^{4}$, managed by France Agrimer for the account of the Direction des Pêches Maritimes et de l'Aquaculture (DPMA) and are made available to Ifremer's Fishing Information System $(\mathrm{SIH})^{5}$.

The flow of information from the RIC allows us to obtain a detailed description of the sales concluded at auction: identification of the vessel, the date and the type of sale, description by commercial species (status, presentation, commercial category, quantity and total amount of the sale) and buyer identification. The flow of information from the RIC is completed by the information on the vessels available in SIH database containing details of fishing vessel activity and in the Community

\footnotetext{
4 According to Commission Regulation (EC) No 1077/2008 of 3 November 2008 laying down detailed rules for the implementation of Council Regulation (EC) No 1966/2006 on electronic recording and reporting of fishing activities and on means of remote sensing and repealing Regulation (EC) No 1566/2007.

${ }^{5} \mathrm{http}: / /$ sih.ifremer.fr/
} 
fishing fleet Register ${ }^{6}$. The Register of Commerce and Companies ${ }^{7}$ provides detailed information about buyers. The variables used in the models (Table 3) are taken from these different information sources. The descriptive statistics concerning the variables used in each of the models featuring in the appendix. In this table are also given references from the current literature considering the same types of variables in the study of mechanisms of price formation in the case of seafood products.

The dependent variable (price per unit) corresponds to the price per unit of scallops at which a batch is exchanged between a seller and a buyer at a defined date and in a given location (Management Area) ${ }^{8}$. A batch corresponds in this way to the object of any given transaction. To each batch corresponds one type of transaction (auction/contract/mutual agreement) and one size of scallop (small size/medium size/large size).

The months of the year (January to December) are tested to the extent that previous studies mention that there exists a certain seasonality in consumption habits for this product independently of the seasonality of production (Abso Conseil, 2010). In order to take market conditions into account, daily production at local and national scales (local daily supply and national daily supply) and the number of buyers (nb of buyers) are included in the analysis. Seller production (vol/\%) and buyer purchase (vol/\%) represent the scallop daily market shares of the different operators expressed either as a quantity, or as a percentage.

\footnotetext{
${ }^{6} \mathrm{http}: / /$ ec.europa.eu/fisheries/fleet/

${ }^{7} \mathrm{https}: / /$ www.infogreffe.fr/societes/

${ }^{8}$ A previous study (Foucher, et al., 2015) showed that there is as many markets as management areas. This explains why we perform a model for each management area. The potential interdependence of markets however taken into account through the variable "national daily supply". A consequence of the existence of eight markets is that explanatory variables of price are not the same for all models.
} 
Table 3. Independent variables used in models

\begin{tabular}{|c|c|c|c|}
\hline Variable & Coding & Label & References in the current literature \\
\hline \multicolumn{4}{|l|}{ Forms/modes of sale } \\
\hline \multirow[t]{3}{*}{ Type of transaction } & auction & auction & \multirow{3}{*}{$\begin{array}{l}\text { Salayo et al., 1999*; Carroll et al., 2001*; Helstad et } \\
\text { al., } 2005\end{array}$} \\
\hline & contract & contract & \\
\hline & mutual agreement & mutual agreement & \\
\hline \multicolumn{4}{|l|}{ Size } \\
\hline \multirow[t]{3}{*}{ Product category } & Small size & european categorization of scallops UE10 & \multirow{3}{*}{$\begin{array}{l}\text { Salayo et al., 1999*; McConnell and Strand, 2000*; } \\
\text { Asche and Guttormsen, 2001; Carroll et al., 2001*; } \\
\text { Helstad et al., 2005; Kristofersson and Rickertsen, } \\
\text { 2007*; Asche and Guillen, 2012*; Fluvià et al., 2012; } \\
\text { Le Floc'h et al., 2012; Zimmermann and Heino, 2013; } \\
\text { Dey et al., 2014; Sogn-Grundvag et al., 2014* }\end{array}$} \\
\hline & Large size & european categorization of scallops UE11 & \\
\hline & Medium size & european categorization of scallops UE12 & \\
\hline \multicolumn{4}{|l|}{ Temporal } \\
\hline \multirow[t]{3}{*}{ Month of the transaction } & January & January & \multirow{3}{*}{$\begin{array}{l}\text { Carroll et al., 2001*; Kristofersson and Rickertsen, } \\
\text { 2007*; Gallegati et al., 2011; Vignes and Etienne, } \\
\text { 2011; Asche and Guillen, 2012*; Fluvià et al., 2012; } \\
\text { Guillen and Maynou, 2014*; Sogn-Grundvag et al., } \\
\text { 2014* }\end{array}$} \\
\hline & $\vdots$ & $\vdots$ & \\
\hline & December & December & \\
\hline \multicolumn{4}{|l|}{ Competition } \\
\hline Number of buyers & nb of buyers & & Helstad et al., 2005; Fluvià et al., 2012 \\
\hline \multicolumn{4}{|l|}{ Quantities } \\
\hline \multirow[t]{2}{*}{ Daily supply (volume) } & local daily supply & local daily supply & \multirow{6}{*}{$\begin{array}{l}\text { Barten and Bettendorf, 1989; Härdle and Kirman, } \\
\text { 1995; McConnell and Strand, 2000*; Carroll et al., } \\
\text { 2001*; Kristofersson and Rickertsen, 2007*; Gallegati } \\
\text { et al., 2011; Fluvià et al., 2012; Dey et al., 2014; } \\
\text { Guillen and Maynou, 2014* }\end{array}$} \\
\hline & national daily supply & national daily supply & \\
\hline \multirow{2}{*}{$\begin{array}{l}\text { Local daily individual } \\
\text { production }\end{array}$} & seller production (vol) & volume produce daily & \\
\hline & seller production $(\%)$ & proportion of the daily production & \\
\hline \multirow{2}{*}{$\begin{array}{l}\text { Local daily individual } \\
\text { purchase }\end{array}$} & buyer purchase (vol) & volume bought daily & \\
\hline & buyer purchase (\%) & proportion of the daily production purchases & \\
\hline
\end{tabular}




\section{Analysis of French scallop price formation}

Table 3. (Continued)

\begin{tabular}{|c|c|c|c|}
\hline Variable & Coding & Label & References \\
\hline \multicolumn{4}{|l|}{ Size of production units } \\
\hline Vessels length & vessel length & length of vessel in meters & Le Floc'h et al., 2012 \\
\hline \multicolumn{4}{|c|}{ Characteristics of operators } \\
\hline \multirow[t]{4}{*}{ Dependence to scallop } & seller dependence (year) & seller annual rate of dependence to scallop & Salayo et al., 1999*; Carroll et al., 2001*; Asche et al., \\
\hline & seller dependence (month) & seller monthly rate of dependence to scallop & $\begin{array}{l}\text { 2002; Vignes and Etienne, 2011; Sogn-Grundvag et } \\
\text { al 2013* }\end{array}$ \\
\hline & buyer dependence (year) & buyer annual rate of dependence to scallop & \\
\hline & buyer dependence (month) & buyer monthly rate of dependence to scallop & \\
\hline \multirow[t]{9}{*}{ Type of buyers } & buyer type: other & other type of buyer & \\
\hline & buyer type: wholesaler & wholesaler & \\
\hline & buyer type: supermarket & supermarket & \\
\hline & buyer type: fish merchant & fish merchant & \\
\hline & buyer type: fisher & fisher & \\
\hline & buyer type: fishmonger & fishmonger & \\
\hline & buyer type: transformer & processor & \\
\hline & buyer importer & scallop importer & \\
\hline & buyer exporter & scallop exporter & \\
\hline \multirow[t]{2}{*}{ Diligence rate } & diligence rate (S) & seller diligence rate & \\
\hline & diligence rate (B) & buyer diligence rate & \\
\hline
\end{tabular}

\section{Loyalty}

Relationships between operators

seller loyalty rate (lot) seller loyalty rate (vol) buyer loyalty rate (lot) buyer loyalty rate (vol) seller loyalty rate based on number of transactions seller loyalty rate based on volume exchange buyer loyalty rate based on number of transactions buyer loyalty rate based on volume exchange
Kirman and Vriend, 2000; Gallegati et al., 2011; Vignes and Etienne, 2011; Cirillo et al., 2012; Fluvià et al., 2012

Note: 'S' or 'B' indicate variable concerning respectively sellers or buyers.

* Articles using a hedonic price modelling 
The economic dependence of operators (seller dependence (year/ month), buyer dependence (year/month)) is here measured by the proportion of scallop in the total turnover figure for sales (purchases) of fishing firms (buyers), considering either the monthly or annual scale.

The variables seller loyalty rate (lot), buyer loyalty rate (lot) correspond to the number of transactions concluded between a seller (buyer) and a buyer (seller), as compared with the total number of transactions concluded by the seller (buyer) over the period studied independently of the quantities exchanged. The variables seller loyalty rate (vol), buyer loyalty rate (vol) are calculated according to the same principle, this time integrating the quantities exchanged independently of the number of transactions. Finally, operator assiduity is introduced via the presence rate (diligence rate $(S / B)$ ). This rate expresses the ratio between the number of days where the buyer (seller) has been active in the primary fish market, and the total number of days of sale of scallops in this same primary fish market.

The position of the buyer on the international scallop market (buyer importer and buyer exporter) and the type of activity involved (buyer type: fish merchant, buyer type: fishmonger, etc.) are also considered as possible factors in explaining variability in the price of scallops.

\section{RESULTS}

\section{Market conditions}

Among the sources of variability of scallop prices in a given management area explored, the sensitivity due to the relationship between prices and quantities (local and national supply) was considered. For the markets under consideration, the pertinent relationship is given by an inverse demand curve, the quantity of scallops 
landed locally each day (local daily supply) being strongly constrained by the specific system of regulation to each zone. The results are significant for all zones with negative price-quantity flexibility coefficients. These coefficients are relatively weak (-0.03 and -0.05$)$ for the two main production zones MA_3 and MA_6 (Tables 4(a) to 4(h)). For the other zones, the higher the estimated coefficient, the lower the production level.

Even though the products sourced by the different fishing grounds are heterogeneous, the significance of the variable national daily supply for all management areas indicates that there is a certain substitutability between products sourced from different management areas. However, the degree of interaction is relatively high for both the main production zones and in particular for zone MA_6. This is much lower, and up to 450 times lower for the other production zones. This leads us to believe that while a certain integration of markets does exist, it is only partial.

The results also show that the higher the number of buyers (nb of buyers) in each market place, the higher the prices will be. This expected effect of the number of buyers on the conditions of competition and price formation is meanwhile specific to each zone. This differentiated effect depending on the zone is, at this stage, difficult to explain. 
Table 4. Estimation results for each management area models of scallop price

\begin{tabular}{|c|c|c|c|c|c|c|c|c|c|c|c|c|c|c|c|c|}
\hline & \multicolumn{2}{|c|}{ MA_1 } & \multicolumn{2}{|c|}{ MA_2 } & \multicolumn{2}{|l|}{ MA_3 } & \multicolumn{2}{|l|}{ MA_4 } & \multicolumn{2}{|l|}{ MA_5 } & \multicolumn{2}{|c|}{ MA_6 } & \multicolumn{2}{|l|}{ MA_7 } & \multicolumn{2}{|c|}{ MA_8 } \\
\hline & $\beta$ & ME & $\beta$ & $\mathrm{ME}$ & $\beta$ & ME & $\beta$ & ME & $\beta$ & ME & $\beta$ & ME & $\beta$ & ME & $\beta$ & $\mathrm{ME}$ \\
\hline _cons & $\begin{array}{c}2.32 \\
1\end{array}$ & & $1.945 * * *$ & & $1.148 * * *$ & & $0.826 * * *$ & & $1.984 * * *$ & & $2.03 * * *$ & & $1.989 * * *$ & & $2.235 * * *$ & \\
\hline auction & & & & & $0.033 * * *$ & 3.37 & & & $-0.046 * *$ & -4.53 & & & & & $0.013 * *$ & 1.26 \\
\hline contract & & & & & $0.066 * * *$ & 6.81 & & & & & $-0.096 * * *$ & -9.11 & $-0.064 * * *$ & -6.17 & & \\
\hline mutual agreement & & & & & & & $0.032 * * *$ & 3.26 & & & $-0.065 * *$ & -6.28 & $-0.06 * * *$ & -5.79 & & \\
\hline small size & & & & & & & & & & & $-0.027 * * *$ & -2.71 & & & & \\
\hline large size & & & & & & & & & & & $0.268 * * *$ & 30.68 & $0.042 * * *$ & 4.31 & $0.017 * *$ & 1.74 \\
\hline January & $\begin{array}{c}- \\
0.23^{* * *} \\
8\end{array}$ & 21.21 & $-0.285 * * *$ & 24.82 & $-0.052 * * *$ & -5.04 & & & $-0.21 * * *$ & $18.93^{-}$ & & & $0.073 * * *$ & 7.57 & & \\
\hline February & $\begin{array}{c}- \\
0.08 * * * \\
1\end{array}$ & -7.73 & & & $-0.05 * * *$ & -4.82 & & & $-0.179 * * *$ & $16.41^{-}$ & $-0.084 * * *$ & -8.01 & & & & \\
\hline March & $0.09 * * *$ & 9.39 & & & $-0.058 * * *$ & -5.58 & $-0.034 * * *$ & -3.38 & $-0.16 * * *$ & 14.79 & & & $-0.021 * * *$ & -2.12 & & \\
\hline April & ${ }_{2}^{0.17}$ *** & 18.8 & & & $-0.019 * *$ & -1.91 & $0.207 * * *$ & 22.98 & $0.035 * *$ & 3.58 & $0.044 * * *$ & 4.51 & $0.056 * * *$ & 5.71 & $0.157 * * *$ & 16.95 \\
\hline May & & & & & & & & & & & $-0.145 * * *$ & $13.48^{-}$ & & & & \\
\hline October & & & $-0.178 * * *$ & 16.31 & & & & & $-0.225 * * *$ & 20.16 & $-0.102 * * *$ & -9.68 & $-0.085 * * *$ & -8.12 & $-0.159 * * *$ & 14.66 \\
\hline November & & & & & $0.046 * * *$ & 4.72 & $0.155 * * *$ & 16.71 & & & & & & & & \\
\hline December & $\begin{array}{c}0.15_{* * *} \\
1\end{array}$ & 16.32 & & & & & $0.049 * * *$ & 4.96 & $-0.109 * * *$ & $10.35^{-}$ & $0.033 * * *$ & 3.38 & & & $0.047 * * *$ & 4.82 \\
\hline $\mathrm{nb}$ of buyers & ${ }^{0.06}{ }^{* * *}$ & 0.06 & $0.007 * * *$ & $1 e-03$ & $0.001 * * *$ & $\begin{array}{r}5 e- \\
04\end{array}$ & $0.014 * *$ & 0.01 & $0.057 * * *$ & 0.06 & $0.028 * * *$ & 0.03 & $0.019 * *$ & 0.02 & $0.008 * * *$ & $2 \mathrm{e}-03$ \\
\hline local daily supply & $0.20^{* * *}$ & -0.2 & $-0.134 * * *$ & -0.13 & $-0.03 * * *$ & -0.03 & $-0.013 * * *$ & -0.01 & $-0.121 * * *$ & -0.12 & $-0.053 * * *$ & -0.05 & $-0.12 * * *$ & -0.12 & $-0.148 * * *$ & -0.15 \\
\hline national daily supply & $3 \mathrm{e}-* * *$ & $4 e-04$ & $-1 e-07 \dagger$ & $-2 \mathrm{e}-$ & $-0.008 * *$ & -0.01 & $-3 e-07 * * *$ & $-3 e-$ & $-4 \mathrm{e}-07 * * *$ & $-4 \mathrm{e}-$ & $-0.049 * * *$ & -0.05 & $-1 \mathrm{e}-07 * *$ & $-1 \mathrm{e}-$ & $-0.008 * * *$ & -0.01 \\
\hline
\end{tabular}


Analysis of French scallop price formation

\begin{tabular}{|c|c|c|c|c|c|c|c|c|c|c|c|c|c|c|c|c|}
\hline & 07 & & & 04 & & & & 04 & & 04 & & & & 04 & & \\
\hline seller production & & & & & $0.005 *$ & $\begin{array}{r}5 e- \\
03\end{array}$ & & & $-0.027 * * *$ & -0.03 & & & $-0.023 * * *$ & -0.02 & $0.008 *$ & 0.01 \\
\hline buyer purchase & $\begin{array}{c}0.00 * * * \\
4\end{array}$ & $\begin{array}{r}-7 e- \\
04\end{array}$ & $-0.024 * *$ & -0.02 & & & $0.001 * * *$ & $1 e-04$ & $-0.028 * * *$ & -0.03 & $-0.011 * * *$ & -0.01 & $-0.01 * *$ & -0.01 & $-0.017 * * *$ & -0.02 \\
\hline vessel length & $\begin{array}{c}0.07 \\
\quad 9\end{array}$ & 0.08 & $0.061 *$ & 0.06 & $0.011 \dagger$ & 0.01 & & & $0.006 * *$ & $8 \mathrm{e}-04$ & & & $0.042 *$ & 0.04 & $0.058 * * *$ & 0.06 \\
\hline seller dependence & & & & & & & & & $-3 \mathrm{e}-04 *$ & $\begin{array}{r}-2 \mathrm{e}- \\
04\end{array}$ & $-0.024 *$ & -0.02 & & & $-0.026 * *$ & -0.03 \\
\hline buyer type: other & $\begin{array}{c}0.15 \text { *** } \\
4\end{array}$ & 14.25 & & & & & & & & & & & & & & \\
\hline $\begin{array}{l}\text { buyer type: } \\
\text { wholesaler }\end{array}$ & & & & & & & & & & & $0.028 * *$ & 2.84 & & & & \\
\hline $\begin{array}{l}\text { buyer type: } \\
\text { supermarket }\end{array}$ & & & $-0.033 * *$ & -3.26 & & & & & & & & & & & & \\
\hline $\begin{array}{l}\text { buyer type: fish } \\
\text { merchant }\end{array}$ & & & & & $-0.027^{* * *}$ & -2.65 & & & $-0.049 * * *$ & -4.74 & & & $-0.034 * * *$ & -3.36 & & \\
\hline
\end{tabular}


Analysis of French scallop price formation

Table 4. (Continued)

\begin{tabular}{|c|c|c|c|c|c|c|c|c|c|c|c|c|c|c|c|c|}
\hline & \multicolumn{2}{|c|}{ MA_1 } & \multicolumn{2}{|c|}{ MA_2 } & \multicolumn{2}{|c|}{ MA_3 } & \multicolumn{2}{|c|}{ MA 4} & \multicolumn{2}{|c|}{ MA_5 } & \multicolumn{2}{|c|}{ MA_6 } & \multicolumn{2}{|c|}{ MA 7} & \multicolumn{2}{|c|}{ MA_ 8} \\
\hline & $\beta$ & $\mathrm{ME}$ & $\beta$ & $\mathrm{ME}$ & $\beta$ & ME & $\beta$ & $\mathrm{ME}$ & $\beta$ & ME & $\beta$ & ME & $\beta$ & ME & $\beta$ & $\mathrm{ME}$ \\
\hline buyer type: transformer & & & & & & & & & $-0.055 * * *$ & -5.36 & & & $-0.042 * * *$ & -4.15 & & \\
\hline buyer importer & & & & & $-0.014 * *$ & -1.39 & & & $-0.02 * *$ & -1.94 & & & $-0.07 * * *$ & -6.74 & $-0.03 * * *$ & -2.92 \\
\hline buyer exporter & $0.042 * * *$ & 4.28 & & & $-0.014 * *$ & -1.39 & & & $0.034 * * *$ & 3.45 & & & & & $0.018 * *$ & 1.79 \\
\hline diligence rate (S) & $0.073 * * *$ & 0.07 & & & & & $4 \mathrm{e}-04 * * *$ & $2 \mathrm{e}-04$ & $0.002 * * *$ & $6 e-04$ & $0.008 *$ & 0.01 & $0.022 * * *$ & 0.02 & & \\
\hline diligence rate (B) & & & & & & & $-2 \mathrm{e}-04 *$ & $-7 e-05$ & & & & & & & $0.001 * * *$ & $2 \mathrm{e}-04$ \\
\hline seller loyalty rate & $0.023 * * *$ & 0.02 & $0.003 *$ & $2 \mathrm{e}-04$ & $-0.007 * * *$ & -0.01 & $0.009 * * *$ & 0.01 & $0.004 * * *$ & $3 e-04$ & $0.004 *$ & $4 e-03$ & $0.025^{* * *}$ & 0.03 & $-0.002 * *$ & $-8 \mathrm{e}-05$ \\
\hline buyer loyalty rate & $-0.013 * *$ & -0.01 & & & $-0.003 * *$ & $-3 e-03$ & $-0.017 * * *$ & -0.02 & $-0.009 * *$ & -0.01 & & & $-0.016^{* * *}$ & -0.02 & & \\
\hline Observations & 204 & & & & 671 & & 193 & & 405 & & 84 & & 4196 & & 360 & \\
\hline $\mathrm{R}^{2}$ & 0.63 & & & & 0.35 & & 0.46 & & 0.44 & & 0.4 & & 0.380 & & 0.51 & \\
\hline
\end{tabular}

Notes: ME: marginal effect. In the case of all continuous variables, marginal effects are indicated for a 1\% change in the level of the variable concerned.

Significance levels: $\uparrow p<0.1 * p<0.05 * * p<0.01 * * * p<0.001$ 


\section{Relationships and behaviour of operators}

Interpersonal relationships (the effects of loyalty) were characterised while considering either the number of transactions concluded, or the quantities exchanged between buyers and sellers (seller loyalty rate (lot/vol), buyer loyalty rate (lot/vol)).

The results show overall that the larger the volumes exchanged with particular sellers, the lower the prices concluded for those transactions. The same type of effect exists for sellers, but only in certain zones. When we consider loyalty in terms of the frequency of transactions, the results show that the more sellers remain loyal to particular buyers, the higher are the prices. This type of effect is almost non-existent for buyers. When we compare the overall marginal effects of loyalty rates in the different production grounds we observe greater sensitivity of prices to the frequency of transactions between a seller and the same buyer for the scallop stocks in management areas MA_1, 2, 6, 7. For the other scallop stocks, there is greater sensitivity to the quantities exchanged between one buyer and a single seller.

To these effects of loyalty seem to be added the effects of assiduity, as defined by the frequency with which operators are present in the different management areas (diligence rate $(S / B))$. The effects concern sellers to a greater extent than buyers. For the latter, only two zones are concerned with the different effects that do not allow us to draw clear conclusions on the impact of this variable on prices. Conversely, in the case of sellers, the effect is positive for two thirds of the zones concerned, which highlights the existence of a clear 'assiduity gain', or advantage. The more specific the product range considered (scallop with coral or larger size), the higher this effect seems to be. 
The results show also that there exists a negative relationship between the market share of a buyer (buyer purchase (\%)) in the management area and the transaction price. This effect has a tendency to cancel itself out for the two main management areas where production and the number of buyers are high. Finally, when several types of transaction exist within each management area, we note that sale by auction will give more added value to scallops than to other types of transaction (over the counter sales, or contract). This is particularly true in the East of the Channel.

\section{Characteristics of operators}

Besides relationships between operators, different individual characteristics of operators were tested. The economic dependence of sellers and buyers (seller dependence rate (year/month), buyer dependence rate (year/month)) vis-à-vis scallops is a variable of considerable interest since it allows us to take into account the opportunities and constraints of operators. The dependence of fishers influences prices negatively only in the management areas furthest to the East, where in other respects, over the counter sales concluded between buyers and sellers are the most frequent. We can observe the opposite effect as regards buyers who, the more dependent they are, appear globally more willing to buy the more expensive scallops. Meanwhile, we may note certain exceptions in management areas MA_3 and 7. This result may notably be explained by the presence of processing operators specialising in scallops, and for whom the purchasing behaviours are different from other buyers.

Where these are significant, the effects of buyers status on prices are those as expected. Globally, willingness to pay will be higher when the buyer is a direct intermediary between the fisher and the end consumer. So, on average, and for a same management area, the consent of the fish merchants is higher than that of the 
fishmongers, or that of the transformers, the fish merchants selling directly to the end consumer. Conversely, among fishmongers who are just intermediaries for wholesalers and central purchasing unit of supermarket chains, there is less willingness to pay.

The integration of buyers in international trade, as measured by the fact of being an importer (buyer importer) or exporter of scallops (buyer exporter), also has a negative and positive influence on the purchase price respectively. This means that willingness to pay of importer buyers (exporters) is relatively lower (relatively higher) than it would be for non-importers (non-exporters). The negative effect is explained quite easily since fresh scallops are imported at lower prices than market prices in France (Abso Conseil, 2010). When it is significant, this effect tends to strengthen in the East of the zone to the extent that a major proportion of imports take place in these areas.

\section{Consumers preferences}

While systems of management influence the structure of demand, the latter is also linked to consumer preferences. So parameter estimates concerning monthly effects (January to December) confirm previous qualitative studies (Abso Conseil, 2010), that note the existence of a degree of seasonality in consumption habits for this product independent of the seasonality of production. The scallop has always been considered a festive item, with consumption increasing during Catholic feast periods (December and April for Christmas and Easter respectively) with positive effects on prices. Other effects linked to the preferences of consumers are identified. In areas where scallops are sorted into different classes based on size (Eastern Channel), there 
is a positive relationship between scallop size (small size/medium size/large size) and the price.

This type of result is consistent with other studies, the larger-sized products being often preferred by end consumers (Gates, 1974). Even while the effects linked to the quality of the products ${ }^{9}$ are not significant, there can be a differentiation of products within each management zone. In the case of the scallop, and biological marine resources generally, the dynamic of the species relies on the nature of the exploited habitats (Engel et al., 1999; Knudby et al., 2010). Even while it is not possible to differentiate the various fishing zones within each management zone in detail, the size of vessels (vessel length) can be used as a good proxy of the gradient of exploitation (distance to the coast) to the extent that there is a good correlation between this and the vessel size (Guyader et al., 2013). The significant and positive (0.06-0.08) influence of vessel length on price for most of the management areas seems to confirm the existence of scallops of different quality, better valorised on the market and non-accessible to smaller fishing units.

\section{DISCUSSION}

The results obtained in our estimations are consistent with those of studies on price formation mechanisms for fish at the primary fish market. So the intrinsic characteristics of scallops such as size or quality, and consumer preferences explain the variability of prices.

Price-quantity relationships (local daily supply, national daily supply) reveal the existence of two value chain models. On the one hand, we find production zones

\footnotetext{
9 The product quality here refers to the appreciation criteria as defined by European regulation (Council Regulation (EC) No 2406/96 of 26 November 1996 laying down common marketing standards for certain fishery products).
} 
oriented towards local markets or niche markets with capacities for absorption that are relatively limited; and on the other hand, there are two production zones more destined to the national market, with a purchasing structure characterised by the presence of transformers and fishmongers capable of absorbing variations in production (MA_3 et MA_6).

Price-quantity relationships that are revealed also translate the differences of perception on the part of buyers, depending on the position they occupy in the supply side of the value chain relatively to the end consumer. As fish products from the two main scallop stocks studied (mainly in the case of MA_3) are destined to supply the sea food transformation sector, the inherent quality of the scallops are less a criterion for purchasing on the primary fish market. For buyers in these zones, scallops are perceived as being relatively homogeneous, and this makes them more sensitive to variations in national production.

The different levels of price sensitivity with regard to the 'loyalty effects' we considered, depending on the type of operator and the type of relationship, do not seem to be linked to the size of the management areas, nor to the structure of the market. However, as indicated earlier, as far as buyers are concerned, it is possible to link loyalty effects with assiduity effects. These assiduity effects would then reflect any effects of reputation that are always exacerbated in the case of products that are more specific (scallop with coral, larger size, or scallop destined for the transformation sector). In scallop stocks where buyers are looking for a particular level of product quality, only the more assiduous sellers will be identifiably able to guarantee buyers the quality they are seeking.

Operator characteristics are also be quite instructive to understand price formation mechanisms for scallops. As the results show, the constraints borne by operators 
linked to their dependence, have a direct effect on price. So we conclude that the more dependent sellers will agree to lower prices, and the more dependent buyers to higher prices. Nonetheless, we should draw a distinction between this latter result in the case of transformers. Because of their specialisation, they exhibit a dependence on the scallop that is relatively high because their purchases of sea food concern almost exclusively this species. The willingness to pay of this type of operator is therefore not linked to their dependence vis-à-vis the scallop, but is linked to the power of negotiation they have by dint of the volumes purchased.

This can be seen to be the more justifiable in proportion to the degree of transformation the scallops are subject to before resale, engendering additional costs in relation to buyers direct linked with the end consumer. This is confirmed, moreover, by our results concerning buyer types. The latter show that prices can vary depending on the level at which the buyer is situated in relation to the end consumer (as a direct intermediary between fisher and end consumer, or as an intermediary between fisher and another intermediary). As indicated earlier, for the transformers that must shell and freeze the scallops before they are sold on to supermarket chains or specialised distribution networks, the pressure exerted by downstream operators can be very strong, explaining their relative lack of willingness to pay for the scallops as compared with fish merchants. Following through, we have shown that for all types of buyers who do not sell directly to the end consumer, the pressure likely to be exerted downstream of the supply chain will ultimately translate into the pressure on fishers that yields lower prices.

The low substitutability of scallops on the French markets, linked partly to scallop quality that varies according to the characteristics of the scallop stocks, is also due in fact to the scallop being a niche product outside the national territory. Generally 
speaking, the positive link established between the exporter status of the buyer, and the price, could be interpreted as a kind of market tension on the offering expressed as a certain buyer overbidding. This is not the case as regards the scallop. As regards the latter, the effect can be explained above all by the fact that exported products target specific markets where the prices negotiated are relatively high. Demand for these market segments corresponds to niche products available only in certain zones (MA_1, MA5 and MA_8).

\section{CONCLUSION}

The various scallop fisheries in the Channel are managed differently to take into account their ecological, biological or socio-economic characteristics. This engenders a relatively heterogeneous range of products landed and sold on in the different auction halls in the Channel, with as many sub-markets as there are management zone-systems. However, the products landed are relatively homogeneous within each management zone because they are produced under quite similar conditions. Notwithstanding, there is no corresponding homogeneity among the prices set for products that have the same identified characteristics.

These differences in price could be explained by the presence of characteristics that are different from those usually highlighted in current literature on price determinants for fish on primary markets. We have notably shown that operator loyalty and assiduity effects also contribute to price formation mechanisms. Are these effects specific to particular instances? Can one show the existence of similar effects in other fisheries that are regulated differently, or that have a less segmented market? In other respects, it is a question of knowing whether the relationships that become established between two particular operators are linked to the characteristics 
Analysis of French scallop price formation

of the fishery, or more to those of the operators. To answer these questions, we would need to conduct a comparative study of different fisheries that included analysis of both characteristics and behaviours of operators. 


\section{REFERENCES}

Abso Conseil (2010) Etude économique sur le marché de la coquille Saint Jacques et des pectinidés en France et dans l'Union Européenne, FranceAgriMer, Paris.

Alban, F. and Boncoeur, J. (2008) Sea Ranching and Self-Management in the Bay of Brest (France): Technical Change and Institutional Adaptation of a Scallop Fishery, in Case Studies in Fisheries Self-Governance, R. Townsend and R. Shotton, (Eds.), FAO Fisheries Technical papers n504, Rome, pp.41-52.

Alfnes, F., Guttormsen, A. G., Steine, G. and Kolstad K. (2006) Consumers' willingness to pay for the color of salmon: a choice experiment with real economic incentives, American Journal of Agricultural Economics, 88, 1050-61.

Arzel, P., Guyader, O. and Kervarec, F. (2005) Sea Ranching and Self-Management in the Bay of Brest (France): Technical Change and Institutional Adaptation of a Scallop Fishery, Publications électroniques Amure, Working Papers Series D-04$2005,18 \mathrm{p}$.

Asche, F., Flaaten, O., Isaksen, J. R. and Vassdal, T. (2002) Derived demand and relationships between prices at different levels in the value chain: a note, Journal of Agricultural Economics, 53, 101-107.

Asche, F. and Guillen, J. (2012) The importance of fishing method, gear and origin: the Spanish hake market, Marine Policy, 36, 365-369.

Asche, F. and Guttormsen, A. G. (2001) Patterns in the relative price for different sizes of farmed fish, Marine Resource Economics, 16, 235-247.

Barten, A. P. and Bettendorf, L. J. (1989) Price formation of fish: an application of an inverse demand system, European Economic Review, 33, 1506-25. 
Binet, T. (2010) Rebuilding the scallop fishery in St. Brieuc Bay, France, Rebuilding Fisheries: The Way Forward, Background Report, OECD Publishing.

BjØrndal, T., Salvanes, K. G. and Andreassen, J. H. (1992) The demand for salmon in France: the effects of marketing and structural change, Applied Economics, 24, $1027-34$

Carroll, M., Anderson, J. L. and Martinez-Garmendia, J. (2001) Pricing U.S. North Atlantic bluefin tuna and implications for management, Agribusiness, 17, 243254.

Cirillo, P., Tedeschi, G. and Gallegati, M. (2012) The Boulogne fish market: the social structure and the role of loyalty, Applied Economics Letters, 19, 1075-79.

Dey, M. M., Rabbani, A. G., Singh, K. and Engle, C. R. (2014) Determinants of retail price and sales volume of catfish products in the United States: an application of retail scanner data, Aquaculture Economics \& Management, 18, $120-148$.

Eales, J. S and Unnevehr, L. J. (1994) The inverse almost ideal demand system, European Economic Review, 38, 101-115.

Engel, D. W., Thayer, G. W. and Evans, D. W. (1999) Linkages between fishery habitat quality, stressors, and fishery populations, Environmental Science and Policy, 2, 465-475.

Fifas, S., Guyader, O. and Boucher, J. (2003) The Pecten fishery in the Bay of SaintBrieuc. Productivity and management, Rapp. Sci. Technol., Acad. Sci. Paris, No 17.

Fluvià, M., Garriga, A., Rigall-I-Torrent, R., Rodríguez-Carámbula, E. and Saló, A. (2012) Buyer and seller behavior in fish markets organized as Dutch auctions: 
Evidence from a wholesale fish market in Southern Europe, Fisheries Research, 127-128, 18-25.

Foucher, E., Blanchard, M., Cugier, P., Desroy, N., Dreanno, C., Fauchot, J, Fifas, S., Guyader, O., Jean, F., Le Gallic, B., Riou, P., Schapira, M. et Thiebaut, E. (2015). Le projet ANR-COMANCHE 2010-STRA-010. Interactions écosystémiques et impacts anthropiques dans les populations de COquilles SaintJacques (Pecten maximus) de la MANCHE. Rapport scientifique final, 38 p.

Gallegati, M., Giulioni, G., Kirman, A. and Palestrini, A. (2011) What's that got to do with the price of fish? Buyers behavior on the Ancona fish market, Journal of Economic Behavior and Organization, 80, 20-33.

Gates, J. M. (1974) Demand price, fish size and the price of fish, Canadian Journal of Agricultural Economics/Revue Canadienne d'Agroéconomie, 22, 1-12.

Guillen, J. and Maynou, F. (2014) Importance of temporal and spatial factors in the ex-vessel price formation for red shrimp and management implications, Marine Policy, 47, 66-70.

Guillotreau, P. and Jiménez-Toribio, R. (2006) The impact of electronic clock auction systems on shellfish prices: econometric evidence from a structural change model, Journal of Agricultural Economics, 57, 523-546.

Gujarati, D. N. (2004). Econométrie. De Boeck, Ouvertures économiques, 1009 p.

Guyader, O., Berthou, P., Koutsikopoulos, C., Alban, F., Demaneche, S., Gaspar, M. B., Eschbaum, R., Fahy, E., Tully, O., Reynal, L., Curtil, O., Frangoudes, K. and Maynou, F. (2013) Small scale fisheries in Europe: A comparative analysis based on a selection of case studies, Fisheries Research, 140, 1-13. 
Guyader, O., Daurès, F. and Fifas, S. (2004) A Bioeconomic analysis of the impact of decommissioning programs: Application to a limited-entry French scallop fishery, Marine Resource Economics, 19, 225-242.

Härdle, W. and Kirman, A. (1995) Nonclassical demand: A model-free examination of price-quantity relations in the Marseille fish market, Journal of Econometrics, 67, 227-257.

Helstad, K., Vassdal, T., Trondsen, T. and Young, J. (2005) Price Links between Auction and Direct Sales of Fresh and Frozen Fish in North Norway (1997-2003), Marine Resource Economics, 20, 305-322.

Kirman, A. P. and Vriend, N. J. (2001) Evolving market structure: An ACE model of price dispersion and loyalty, Journal of Economic Dynamics \& Control, 25, 459502.

Knudby, A., Brenning, A. and LeDrew, E. (2010) New approaches to modelling fishhabitat relationships, Ecological Modelling, 221, 503-511.

Kristofersson, D. and Rickertsen, K. (2004) Efficient estimation of hedonic inverse input demand systems, American Journal of Agricultural Economics, 86, $1127-$ 37.

Le Floc'h, P., Matei, I. and Tuncel, M. (2012) Commercial sizes and prices on the French monkfish fishery: a time-series analysis, Brussels Economic Review/Cahiers Economiques de Bruxelles, 55, 97-115.

Lesur-Irichabeau, G., Guyader, O. and Frésard, M. (2014) Analyses des relations entre pêcheurs et acheteurs de coquilles Saint-Jacques en criée : quelles conséquences sur la structure du marché ?, Publications électroniques Amure, Working Papers Series, Université de Bretagne Occidentale, in prep. 
Matsuda, T. (2007) Linearizing the inverse quadratic almost ideal demand system, Applied Economics, 39, 391-396.

Matulich, S. C, Mittelhammer, R. C. and Reberte, C. (1996) Toward a more complete model of individual transferable fishing quotas; implications of incorporating the Process sector, Journal of Environmental Economics and Management, 31, 112-128.

McCay, B. J, Creed, C. F., Finlayson, A. C., Apostle, R. and Mikalsen, K. (1995) Individual transferable quotas (ITQs) in Canadian and Us Fisheries, Ocean and Coastal Management, 28, 85-115.

McConnell, K. and Strand, I. E. (2000) Hedonic prices for fish: tuna prices in Hawaii, American Journal of Agricultural Economics, 82, 133-144.

Meunier, M., Daurès, F. and Girard, S. (2013) Etat des lieux des secteurs pêche et aquaculture et de la consommation des produits aquatiques. Approche nationale (France) et régionale (Bretagne), Publications électroniques Amure, Série Rapports R-32-2013, 41p.

OCDE (2012), Rebuilding Fisheries: The Way Forward, Editions OCDE, Paris.

Roheim, C. A., Asche, F. and Santos, J. I. (2011) The elusive price premium for ecolabelled products: evidence from seafood in the UK market, Journal of Agricultural Economics, 62, 655-668.

Roheim, C. A., Gardiner and L., Asche, F. (2007) Value of brands and other attributes: hedonic analyses of retail frozen fish in the UK, Marine Resource Economics, 22, 239-254. 
Salayo, N. D., Voon, T. J. P. and Selvanthan, S. (1999) Implicit price of Prawn and Shrimp attributes in the Philippine domestic market, Marine Resource Economics, $14,65-78$.

Smith, M. D. and Gopalakrishnan, S. (2010) Combining property rights and landings taxes to mitigate the ecological impact of fishing, in Proceedings of the Fifteenth Biennial Conference of the International Institute of Fisheries Economics \& Trade, International Institute of Fisheries Economics \& Trade, Corvallis, Oregon.

Sogn-Grundvag, G., Larsen, T. A. and Young, J. A. (2013) The value of line-caught and other attributes: an exploration of price premiums for chilled fish in UK supermarkets, Marine Policy, 38, 41-44.

Sogn-Grundvag, G., Larsen, T. A. and Young, J. A. (2014) Product differentiation with credence attributes and private labels: the case of whitefish in UK supermarkets, Journal of Agricultural Economics, 65, 368-382.

Terra, S. (2005) Guide des bonnes pratiques pour la mise en oeuvre de la méthode des prix hédoniques, Ministère de l'Ecologie et du Développement Durable, Direction des Etudes Economiques et de l'Evaluation Environnementale, Paris.

Vignes, A. and Etienne, J. M. (2011) Price formation on the Marseille fish market: evidence from a network analysis, Journal of Economic Behavior and Organization, 80, 50-67.

Zimmermann, F. and Heino, M. (2013) Is size-dependent pricing prevalent in fisheries? The case of Norwegian demersal and pelagic fisheries, ICES J. Mar. Sci. first published online August 24, 2013 doi:10.1093/icesjms/fst121. 


\section{APPENDIX}

Tables A. Descriptive statistics

\begin{tabular}{|c|c|c|c|c|c|c|c|c|c|c|c|}
\hline \multicolumn{6}{|c|}{ Table A1. Management area 1 (2040 obs.) } & \multicolumn{6}{|c|}{ Table A2. Management area 2 (1200 obs.) } \\
\hline Variable & Type & Mean & SD & Min & Max & Variable & Type & Mean & SD & Min & Max \\
\hline price per unit & $\log$ & 4.33 & 1.15 & 2 & 8.85 & price per unit & $\log$ & 2.72 & 0.58 & 2 & 5.52 \\
\hline January & dum & 0.17 & 0.37 & 0 & 1 & January & dum & 0.18 & 0.38 & 0 & 1 \\
\hline February & dum & 0.13 & 0.33 & 0 & 1 & October & dum & 0.21 & 0.41 & 0 & 1 \\
\hline March & dum & 0.10 & 0.30 & 0 & 1 & $\mathrm{nb}$ of buyers & norm & 16.36 & 5.68 & 2 & 27 \\
\hline April & dum & 0.01 & 0.12 & 0 & 1 & local daily supply & $\log$ & 3.86 & 1.89 & 0.08 & 10.24 \\
\hline December & dum & 0.26 & 0.44 & 0 & 1 & national daily supply & norm & 132.99 & 63.55 & 2.24 & 277.91 \\
\hline $\mathrm{nb}$ of buyers & $\log$ & 13.32 & 5.19 & 1 & 24 & buyer purchase (\%) & $\log$ & 11.07 & 9.99 & 0.63 & 65.75 \\
\hline local daily supply & $\log$ & 2.31 & 1.39 & 0.1 & 5.88 & vessel length & $\log$ & 11.68 & 2.08 & 7.26 & 14.50 \\
\hline national daily supply & norm & 125.49 & 60.35 & 0 & 285.14 & buyer dependence (month) & $\log$ & 15.58 & 16 & 0.02 & 72.90 \\
\hline buyer purchase (\%) & norm & 14.80 & 16.48 & 0.16 & 100 & buyer type: supermarket & dum & 0.11 & 0.32 & 0 & 1 \\
\hline vessel length & $\log$ & 9.43 & 0.90 & 7.45 & 11.43 & seller loyalty rate (lot) & norm & 5.16 & 4.43 & 0.42 & 25.81 \\
\hline buyer type: other & dum & 0.03 & 0.18 & 0 & 1 & & & & & & \\
\hline buyer type: fisher & dum & 0.21 & 0.41 & 0 & 1 & & & & & & \\
\hline buyer exporter & dum & 0.56 & 0.50 & 0 & 1 & & & & & & \\
\hline seller loyalty rate (lot) & $\log$ & 8.89 & 11.60 & 0.85 & 100 & & & & & & \\
\hline buyer loyalty rate (vol) & $\log$ & 2.98 & 3.70 & 0.01 & 91.82 & & & & & & \\
\hline diligence rate $(\mathrm{S})$ & $\log$ & 41.56 & 15.52 & 1.15 & 64.37 & & & & & & \\
\hline
\end{tabular}

Notes for all tables A: We present only the variables included in the final models.

$\log$ indicates that the variable is in logarithm form, norm indicates that the variable is in normal form and dum indicates that the variable is a dummy Statistics for national daily supply, local daily supply, seller production (vol) and buyer purchase (vol) are in tons. 


\begin{tabular}{|c|c|c|c|c|c|}
\hline \multicolumn{6}{|c|}{ Table A3. Management area 3 (6718 obs.) } \\
\hline Variable & Type & Mean & SD & Min & Max \\
\hline price per unit & $\log$ & 2.14 & 0.17 & 1.7 & 3.14 \\
\hline auction & dum & 0.94 & 0.25 & 0 & 1 \\
\hline contract & dum & 0.02 & 0.14 & 0 & 1 \\
\hline January & dum & 0.06 & 0.23 & 0 & 1 \\
\hline February & dum & 0.16 & 0.37 & 0 & 1 \\
\hline March & dum & 0.29 & 0.45 & 0 & 1 \\
\hline April & dum & 0.04 & 0.20 & 0 & 1 \\
\hline November & dum & 0.17 & 0.38 & 0 & 1 \\
\hline nb of buyers & norm & 62.63 & 26 & 1 & 103 \\
\hline local daily supply & $\log$ & 90.02 & 36.26 & 0.17 & 131.21 \\
\hline national daily supply & $\log$ & 60.97 & 36.48 & 0 & 163 \\
\hline seller production (vol) & $\log$ & 0.76 & 0.38 & 0.02 & 3.08 \\
\hline vessel length & $\log$ & 10.84 & 1.43 & 6.49 & 16 \\
\hline buyer dependence (month) & $\log$ & 68 & 35.17 & 0 & 100 \\
\hline buyer type: fish merchant & dum & 0.07 & 0.25 & 0 & 1 \\
\hline buyer type: fishmonger & dum & 0.38 & 0.48 & 0 & 1 \\
\hline buyer importer & dum & 0.32 & 0.47 & 0 & 1 \\
\hline buyer exporter & dum & 0.56 & 0.50 & 0 & 1 \\
\hline seller loyalty rate (vol) & $\log$ & 41.72 & 33.15 & 0.03 & 100 \\
\hline buyer loyalty rate (vol) & $\log$ & 26.33 & 41.41 & 0 & 100 \\
\hline
\end{tabular}

\begin{tabular}{llrrrr}
\hline \multicolumn{1}{c}{ Table A4. Management area 4 (1939 obs.) } & & & \\
\hline \multicolumn{1}{c}{ Variable } & Type & \multicolumn{1}{c}{ Mean } & \multicolumn{1}{c}{ SD } & \multicolumn{1}{c}{ Min } & \multicolumn{1}{c}{ Max } \\
\hline price per unit & $\log$ & 2.20 & 0.26 & 1.60 & 3.3 \\
mutual agreement & dum & 0.54 & 0.50 & 0 & 1 \\
March & dum & 0.13 & 0.34 & 0 & 1 \\
April & dum & 0.04 & 0.19 & 0 & 1 \\
November & dum & 0.16 & 0.37 & 0 & 1 \\
December & dum & 0.24 & 0.43 & 0 & 1 \\
nb of buyers & $\log$ & 7.08 & 3.19 & 1 & 13 \\
local daily supply & $\log$ & 26.91 & 35.55 & 0.18 & 129.95 \\
national daily supply & norm & 104.30 & 65.84 & 0 & 277.77 \\
buyer purchase (\%) & norm & 9.79 & 7.76 & 0.09 & 65.55 \\
buyer dependence (month) & norm & 65.34 & 34.54 & 2.69 & 100 \\
seller loyalty rate (lot) & $\log$ & 23.91 & 24.88 & 0.23 & 100 \\
buyer loyalty rate (vol) & $\log$ & 13.69 & 17.85 & 0.03 & 63.63 \\
diligence rate (S) & norm & 46.68 & 22.23 & 0.74 & 80 \\
diligence rate (B) & norm & 42.19 & 28.39 & 1.48 & 74.81 \\
\hline
\end{tabular}




\begin{tabular}{|c|c|c|c|c|c|}
\hline \multicolumn{6}{|c|}{ Table A5. Management area 5 (4052 obs.) } \\
\hline Variable & Type & Mean & SD & Min & Max \\
\hline price per unit & $\log$ & 2.43 & 0.56 & 1.78 & 4.49 \\
\hline auction & dum & 0.94 & 0.23 & 0 & 1 \\
\hline January & dum & 0.13 & 0.34 & 0 & 1 \\
\hline February & dum & 0.14 & 0.35 & 0 & 1 \\
\hline March & dum & 0.17 & 0.37 & 0 & 1 \\
\hline April & dum & 0.08 & 0.27 & 0 & 1 \\
\hline October & dum & 0.14 & 0.35 & 0 & 1 \\
\hline December & dum & 0.16 & 0.37 & 0 & 1 \\
\hline nb of buyers & $\log$ & 15.76 & 4.41 & 1 & 24 \\
\hline local daily supply & $\log$ & 9.05 & 6.27 & 0.04 & 27.07 \\
\hline national daily supply & norm & 100.21 & 63.1 & 0 & 277.66 \\
\hline seller production $(\%)$ & $\log$ & 19.31 & 17.11 & 0.04 & 100 \\
\hline buyer purchase (\%) & $\log$ & 11.56 & 12.74 & 0.08 & 100 \\
\hline vessel length & norm & 13.82 & 2.24 & 9.10 & 17.62 \\
\hline seller dependence (year) & norm & 64.31 & 18.40 & 0.55 & 97.23 \\
\hline buyer dependence (year) & norm & 26.47 & 16.88 & 0.15 & 68.40 \\
\hline buyer type: fish merchant & dum & 0.34 & 0.47 & 0 & 1 \\
\hline buyer type: transformer & dum & 0.12 & 0.33 & 0 & 1 \\
\hline buyer importer & dum & 0.39 & 0.49 & 0 & 1 \\
\hline buyer exporter & dum & 0.41 & 0.49 & 0 & 1 \\
\hline seller loyalty rate (lot) & norm & 5.65 & 4.84 & 0.21 & 25.24 \\
\hline buyer loyalty rate (vol) & $\log$ & 6.43 & 6.62 & 0.01 & 100 \\
\hline diligence rate $(\mathrm{S})$ & norm & 37.36 & 18.48 & 2.14 & 69.29 \\
\hline
\end{tabular}

\begin{tabular}{llrrrr}
\hline \multicolumn{1}{c}{ Table A6. Management area 6 (8415 obs.) } & & & \\
\hline Variable & Type & Mean & \multicolumn{1}{c}{ SD } & Min & Max \\
\hline price per unit & log & 2.78 & 0.73 & 2.01 & 6.69 \\
contract & dum & 0.02 & 0.15 & 0 & 1 \\
mutual agreement & dum & 0.01 & 0.09 & 0 & 1 \\
small size & dum & 0.11 & 0.32 & 0 & 1 \\
large size & dum & 0.33 & 0.47 & 0 & 1 \\
February & dum & 0.13 & 0.34 & 0 & 1 \\
April & dum & 0.04 & 0.20 & 0 & 1 \\
May & dum & 0.02 & 0.12 & 0 & 1 \\
October & dum & 0.09 & 0.29 & 0 & 1 \\
December & dum & 0.21 & 0.41 & 0 & 1 \\
nb of buyers & $\log$ & 29.02 & 7.84 & 1 & 42 \\
local daily supply & $\log$ & 40.97 & 27.32 & 0.14 & 166.97 \\
national daily supply & $\log$ & 76.07 & 51.82 & 1.54 & 214.02 \\
buyer purchase (vol) & $\log$ & 2.76 & 5.71 & 0 & 63.07 \\
seller dependence (year) & $\log$ & 81.86 & 13 & 21.10 & 100 \\
buyer dependence (year) & $\log$ & 27.07 & 20.46 & 0.15 & 100 \\
buyer type: wholesaler & $\operatorname{dum}$ & 0.05 & 0.22 & 0 & 1 \\
buyer type: fisher & $\operatorname{dum}$ & 0.02 & 0.13 & 0 & 1 \\
seller loyalty rate (lot) & $\log$ & 7.60 & 9.64 & 0.14 & 100 \\
diligence rate (S) & $\log$ & 33.76 & 12.37 & 0.65 & 54.25 \\
\hline & & & & & \\
\hline
\end{tabular}




\begin{tabular}{llrrrr}
\hline \multicolumn{2}{l}{ Table A7. Management area 7 (4196 obs.) } & \multicolumn{4}{l}{} \\
\hline Variable & Type & Mean & SD & Min & Max \\
\hline price per unit & log & 2.66 & 0.55 & 1.66 & 5.94 \\
contract & dum & 0.01 & 0.11 & 0 & 1 \\
mutual agreement & dum & 0.11 & 0.31 & 0 & 1 \\
large size & dum & 0.72 & 0.45 & 0 & 1 \\
January & dum & 0.14 & 0.35 & 0 & 1 \\
March & dum & 0.15 & 0.35 & 0 & 1 \\
April & dum & 0.08 & 0.28 & 0 & 1 \\
October & dum & 0.14 & 0.35 & 0 & 1 \\
nb of buyers & $\log$ & 15.39 & 5.30 & 1 & 24 \\
local daily supply & $\log$ & 18.59 & 10.51 & 0.20 & 56.24 \\
national daily supply & norm & 91.97 & 61.71 & 0 & 237.76 \\
seller production (\%) & $\log$ & 12.82 & 14.52 & 0.06 & 100 \\
buyer purchase (\%) & $\log$ & 16.06 & 18.36 & 0.05 & 100 \\
vessel length & $\log$ & 15.62 & 2.42 & 9.98 & 20.30 \\
buyer dependence (year) & $\log$ & 44.98 & 23.48 & 0.15 & 100 \\
buyer type: fish merchant & dum & 0.23 & 0.42 & 0 & 1 \\
buyer type: transformer & dum & 0.09 & 0.29 & 0 & 1 \\
buyer importer & dum & 0.38 & 0.49 & 0 & 1 \\
seller loyalty rate (lot) & $\log$ & 14.32 & 21.03 & 0.14 & 100 \\
buyer loyalty rate (vol) & $\log$ & 8.02 & 9.37 & 0.01 & 100 \\
diligence rate (S) & $\log$ & 33.66 & 14.66 & 0.61 & 54.27 \\
\hline
\end{tabular}

\begin{tabular}{|c|c|c|c|c|c|}
\hline \multicolumn{6}{|c|}{ Table A8. Management area 8 (3606 obs.) } \\
\hline Variable & Type & Mean & SD & Min & Max \\
\hline price per unit & $\log$ & 3.02 & 0.53 & 1.8 & 5.11 \\
\hline auction & dum & 0.55 & 0.50 & 0 & 1 \\
\hline large size & dum & 0.16 & 0.37 & 0 & 1 \\
\hline April & dum & 0.06 & 0.23 & 0 & 1 \\
\hline October & dum & 0.15 & 0.35 & 0 & 1 \\
\hline December & dum & 0.19 & 0.39 & 0 & 1 \\
\hline nb of buyers & norm & 21.13 & 7.03 & 1 & 37 \\
\hline local daily supply & $\log$ & 6.32 & 3.33 & 0.09 & 16.20 \\
\hline national daily supply & $\log$ & 99.57 & 70.62 & 0 & 271.96 \\
\hline seller production (\%) & $\log$ & 26.06 & 21.85 & 0.48 & 100 \\
\hline buyer purchase (\%) & $\log$ & 8.08 & 9.05 & 0.20 & 100 \\
\hline vessel length & $\log$ & 16.73 & 4.03 & 9.20 & 24.10 \\
\hline seller dependence (month) & $\log$ & 90.12 & 11.97 & 2.59 & 100 \\
\hline buyer type: fishmonger & dum & 0.59 & 0.49 & 0 & 1 \\
\hline buyer importer & dum & 0.44 & 0.50 & 0 & 1 \\
\hline buyer exporter & dum & 0.52 & 0.50 & 0 & 1 \\
\hline seller loyalty rate (vol) & norm & 5.06 & 5.00 & 0.03 & 100 \\
\hline diligence rate (B) & norm & 48.18 & 21.98 & 0.67 & 79.19 \\
\hline
\end{tabular}


Table B. Estimation results for each management area models of scallop price

\begin{tabular}{|c|c|c|c|c|c|c|c|c|c|c|c|}
\hline \multicolumn{6}{|c|}{ Table B1. MA_1 (2040 obs.) } & \multicolumn{6}{|l|}{ Table B2. MA_2 (1200 obs.) } \\
\hline Variable & VIF & $\beta$ & & $t$-stat & ME & Variable & VIF & $\beta$ & & $t$-stat & ME \\
\hline _cons & & 2.3205 & $* * *$ & 16.84 & & _cons & & 1.9445 & $* * *$ & 19.60 & \\
\hline January & 1.47 & -0.2384 & $* * *$ & -20.11 & -21.21 & January & 1.19 & -0.2852 & $* * *$ & -28.97 & -24.82 \\
\hline February & 1.85 & -0.0805 & $* * *$ & -5.98 & -7.73 & October & 1.21 & -0.1780 & $* * *$ & -17.44 & -16.31 \\
\hline March & 1.95 & 0.0898 & $* * *$ & 5.56 & 9.39 & $\mathrm{nb}$ of buyers & 4.82 & 0.0066 & $* * *$ & 4.87 & $1.0 \mathrm{e}-03$ \\
\hline April & 1.34 & 0.1723 & $* * *$ & 5.76 & 18.80 & local daily supply & 4.68 & -0.1336 & $* * *$ & -10.11 & -0.13 \\
\hline December & 1.40 & 0.1512 & $* * *$ & 12.77 & 16.32 & national daily supply & 1.44 & $-1.4 \mathrm{e}-07$ & $\dagger$ & -1.67 & $-1.9 e-04$ \\
\hline nb of buyers & 3.57 & 0.0632 & $* * *$ & 4.36 & 0.06 & buyer purchase (\%) & 1.62 & -0.0237 & $* *$ & -3.40 & -0.02 \\
\hline local daily supply & 2.91 & -0.2015 & $* * *$ & -16.29 & -0.20 & vessel length & 1.25 & 0.0611 & $*$ & 2.37 & 0.06 \\
\hline national daily supply & 1.21 & $3.0 \mathrm{e}-07$ & $* * *$ & 4.94 & $3.8 \mathrm{e}-04$ & buyer dependence (month) & 1.48 & 0.0071 & * & 2.18 & 0.01 \\
\hline buyer purchase (\%) & 3.08 & -0.0044 & $* * *$ & -9.03 & $-6.5 \mathrm{e}-04$ & buyer type: supermarket & 1.23 & -0.0332 & $* *$ & -2.76 & -3.26 \\
\hline vessel length & 1.09 & 0.0792 & $*$ & 1.97 & 0.08 & seller loyalty rate (lot) & 1.21 & 0.0032 & $* *$ & 2.71 & $1.6 \mathrm{e}-04$ \\
\hline buyer type: other & 1.75 & -0.1537 & $* * *$ & -6.83 & -14.25 & $\mathrm{R}^{2}$ & & 0.4094 & & & \\
\hline buyer type: fisher & 1.65 & 0.0257 & $\dagger$ & 1.93 & 2.60 & & & & & & \\
\hline buyer exporter & 1.46 & 0.0419 & $* * *$ & 4.45 & 4.28 & & & & & & \\
\hline seller loyalty rate (lot) & 1.52 & 0.0233 & $* * *$ & 3.67 & 0.02 & & & & & & \\
\hline buyer loyalty rate (vol) & 1.23 & -0.0128 & $* *$ & -3.31 & -0.01 & & & & & & \\
\hline diligence rate $(\mathrm{S})$ & 1.37 & 0.0734 & $* * *$ & 8.69 & 0.07 & & & & & & \\
\hline $\mathrm{R}^{2}$ & & 0.6334 & & & & & & & & & \\
\hline
\end{tabular}


Analysis of French scallop price formation

\begin{tabular}{|c|c|c|c|c|c|c|c|c|c|c|c|}
\hline \multicolumn{6}{|l|}{ Table B3. MA_3 (6718 obs.) } & \multicolumn{6}{|l|}{ Table B4. MA_4 (1939 obs.) } \\
\hline Variable & VIF & $\beta$ & & $t$-stat & $\mathrm{ME}$ & Variable & VIF & $\beta$ & & $t$-stat & $\mathrm{ME}$ \\
\hline _cons & & 1.1478 & $* * *$ & 23.06 & & cons & & 0.8258 & $* * *$ & 21.90 & \\
\hline auction & 1.84 & 0.0332 & $* * *$ & 10.03 & 3.37 & mutual agreement & 2.41 & 0.0321 & $* * *$ & 5.44 & 3.26 \\
\hline contract & 1.59 & 0.0659 & $* * *$ & 8.86 & 6.81 & March & 1.38 & -0.0344 & $* * *$ & -6.35 & -3.38 \\
\hline January & 1.31 & -0.0518 & $* * *$ & -11.67 & -5.04 & April & 1.51 & 0.2068 & $* * *$ & 12.76 & 22.98 \\
\hline February & 1.58 & -0.0495 & $* * *$ & -19.19 & -4.82 & November & 1.36 & 0.1545 & $* * *$ & 33.82 & 16.71 \\
\hline March & 1.82 & -0.0575 & $* * *$ & -20.54 & -5.58 & December & 1.60 & 0.0485 & $* * *$ & 8.46 & 4.96 \\
\hline April & 1.76 & -0.0193 & $* *$ & -2.71 & -1.91 & nb of buyers & 2.82 & 0.0135 & $* *$ & 2.79 & 0.01 \\
\hline November & 1.39 & 0.0461 & $* * *$ & 14.80 & 4.72 & local daily supply & 3.61 & -0.0131 & $* * *$ & -3.88 & -0.01 \\
\hline $\mathrm{nb}$ of buyers & 3.03 & 0.0007 & $* * *$ & 11.70 & $4.7 \mathrm{e}-04$ & national daily supply & 1.74 & $-2.5 e-07$ & $* * *$ & -7.00 & $-2.6 e-04$ \\
\hline local daily supply & 3.15 & -0.0300 & $* * *$ & -11.51 & -0.03 & buyer purchase $(\%)$ & 1.67 & 0.0013 & $* * *$ & 4.20 & $1.3 \mathrm{e}-04$ \\
\hline national daily supply & 1.20 & -0.0077 & $* *$ & -3.04 & -0.01 & buyer dependence (month) & 1.47 & 0.0002 & $*$ & 2.43 & $9.9 \mathrm{e}-05$ \\
\hline seller production (vol) & 1.31 & 0.0046 & $*$ & 2.54 & $4.6 \mathrm{e}-03$ & seller loyalty rate (lot) & 2.43 & 0.0092 & $* * *$ & 3.66 & 0.01 \\
\hline vessel length & 1.23 & 0.0105 & $\dagger$ & 1.76 & 0.01 & buyer loyalty rate (vol) & 2.18 & -0.0168 & $* * *$ & -8.84 & -0.02 \\
\hline buyer dependence (month) & 2.59 & -0.0094 & $*$ & -2.36 & -0.01 & diligence rate (S) & 1.21 & 0.0004 & $* * *$ & 3.74 & $1.7 \mathrm{e}-04$ \\
\hline buyer type: fish merchant & 1.68 & -0.0268 & $* * *$ & -5.00 & -2.65 & diligence rate $(\mathrm{B})$ & 2.26 & -0.0002 & $*$ & -1.97 & $-7.3 e-05$ \\
\hline buyer type: fishmonger & 6.39 & -0.0300 & $* * *$ & -5.22 & -2.95 & $\mathrm{R}^{2}$ & & 0.4665 & & & \\
\hline buyer importer & 5.38 & -0.0140 & $* *$ & -2.73 & -1.39 & & & & & & \\
\hline buyer exporter & 4.29 & -0.0140 & $* *$ & -3.30 & -1.39 & & & & & & \\
\hline seller loyalty rate (vol) & 2.68 & -0.0066 & $* * *$ & -5.68 & -0.01 & & & & & & \\
\hline buyer loyalty rate (vol) & 3.67 & -0.0026 & $* *$ & -3.18 & $-2.6 e-03$ & & & & & & \\
\hline $\mathrm{R}^{2}$ & & 0.35 & & & & & & & & & \\
\hline
\end{tabular}


Analysis of French scallop price formation

\begin{tabular}{|c|c|c|c|c|c|}
\hline \multicolumn{6}{|c|}{ Table B5. MA_5 (4052 obs.) } \\
\hline Variable & VIF & $\beta$ & & $t$-stat & ME \\
\hline _cons & & 1.9840 & $* * *$ & 38.65 & \\
\hline auction & 1.11 & -0.0463 & $* *$ & -3.27 & -4.53 \\
\hline January & 1.75 & -0.2099 & $* * *$ & -22.32 & -18.93 \\
\hline February & 2.02 & -0.1792 & $* * *$ & -19.99 & -16.41 \\
\hline March & 1.93 & -0.1600 & $* * *$ & -17.78 & -14.79 \\
\hline April & 1.67 & 0.0352 & $* *$ & 2.76 & 3.58 \\
\hline October & 1.74 & -0.2251 & $* * *$ & -24.94 & -20.16 \\
\hline December & 1.71 & -0.1093 & $* * *$ & -10.49 & -10.35 \\
\hline nb of buyers & 3.08 & 0.0570 & $* * *$ & 4.35 & 0.06 \\
\hline local daily supply & 3.57 & -0.1213 & $* * *$ & -19.82 & -0.12 \\
\hline national daily supply & 1.37 & $-4.1 \mathrm{e}-07$ & $* * *$ & -9.06 & $-4.1 \mathrm{e}-04$ \\
\hline seller production $(\%)$ & 1.62 & -0.0265 & $* * *$ & -6.77 & -0.03 \\
\hline buyer purchase (\%) & 1.77 & -0.0284 & $* * *$ & -10.05 & -0.03 \\
\hline vessel length & 1.75 & 0.0055 & $* *$ & 3.34 & $7.6 e-04$ \\
\hline seller dependence (year) & 1.34 & -0.0003 & $*$ & -2.13 & $-2.1 \mathrm{e}-04$ \\
\hline buyer dependence (year) & 1.55 & 0.0008 & $* * *$ & 4.56 & $2.1 \mathrm{e}-04$ \\
\hline buyer type: fish merchant & 1.80 & -0.0486 & $* * *$ & -6.88 & -4.74 \\
\hline buyer type: transformer & 1.78 & -0.0551 & $* * *$ & -5.59 & -5.36 \\
\hline buyer importer & 2.02 & -0.0196 & $* *$ & -2.84 & -1.94 \\
\hline buyer exporter & 2.43 & 0.0339 & $* * *$ & 4.18 & 3.45 \\
\hline seller loyalty rate (lot) & 2.08 & 0.0044 & $* * *$ & 5.56 & $2.5 \mathrm{e}-04$ \\
\hline buyer loyalty rate (vol) & 1.67 & -0.0089 & $* *$ & -3.47 & -0.01 \\
\hline diligence rate $(\mathrm{S})$ & 2.05 & 0.0016 & $* * *$ & 8.25 & $6.0 \mathrm{e}-04$ \\
\hline $\mathrm{R}^{2}$ & & 0.4455 & & & \\
\hline
\end{tabular}

\begin{tabular}{|c|c|c|c|c|c|}
\hline \multicolumn{6}{|c|}{ Table B6. MA_6 (8415 obs.) } \\
\hline Variable & VIF & $\beta$ & & $t$-stat & $\mathrm{ME}$ \\
\hline _cons & & 2.0299 & $* * *$ & 34.6 & \\
\hline contract & 1.28 & -0.0956 & $* * *$ & -8.10 & -9.11 \\
\hline mutual agreement & 1.03 & -0.0648 & $* *$ & -3.28 & -6.28 \\
\hline small size & 1.36 & -0.0274 & $* * *$ & -5.56 & -2.71 \\
\hline large size & 1.13 & 0.2676 & $* * *$ & 51.73 & 30.68 \\
\hline February & 1.18 & -0.0835 & $* * *$ & -17.77 & -8.01 \\
\hline April & 1.34 & 0.0441 & $* * *$ & 4.44 & 4.51 \\
\hline May & 1.26 & -0.1448 & $* * *$ & -11.13 & -13.48 \\
\hline October & 1.20 & -0.1019 & $* * *$ & -17.22 & -9.68 \\
\hline December & 1.22 & 0.0332 & $* * *$ & 5.37 & 3.38 \\
\hline $\mathrm{nb}$ of buyers & 2.17 & 0.0279 & $* * *$ & 4.01 & 0.03 \\
\hline local daily supply & 2.60 & -0.0528 & $* * *$ & -14.11 & -0.05 \\
\hline national daily supply & 1.38 & -0.0491 & $* * *$ & -19.83 & -0.05 \\
\hline buyer purchase (vol) & 1.69 & -0.0108 & $* * *$ & -8.05 & -0.01 \\
\hline seller dependence (year) & 1.10 & -0.0238 & $*$ & -2.35 & -0.02 \\
\hline buyer dependence (year) & 1.47 & 0.0107 & $* * *$ & 4.59 & 0.01 \\
\hline buyer type: wholesaler & 1.07 & 0.0280 & $* *$ & 3.06 & 2.84 \\
\hline buyer type: fisher & 1.05 & -0.0354 & $* *$ & -3.25 & -3.48 \\
\hline seller loyalty rate (lot) & 1.28 & 0.0043 & $*$ & 2.08 & $4.3 \mathrm{e}-03$ \\
\hline diligence rate $(\mathrm{S})$ & 1.16 & 0.0081 & $*$ & 2.40 & 0.01 \\
\hline $\mathrm{R}^{2}$ & & 0.4458 & & & \\
\hline
\end{tabular}


Analysis of French scallop price formation

\begin{tabular}{|c|c|c|c|c|c|}
\hline \multicolumn{6}{|c|}{ Table B7. MA_7 (4196 obs.) } \\
\hline Variable & VIF & $\beta$ & & $t$-stat & ME \\
\hline _cons & & 1.9888 & $* * *$ & 28.73 & \\
\hline contract & 1.13 & -0.0637 & $* * *$ & -3.82 & -6.17 \\
\hline mutual agreement & 1.37 & -0.0597 & $* * *$ & -8.09 & -5.79 \\
\hline large size & 1.78 & 0.0422 & $* * *$ & 6.90 & 4.31 \\
\hline January & 1.17 & 0.0730 & $* * *$ & 10.86 & 7.57 \\
\hline March & 1.23 & -0.0214 & $* * *$ & -3.78 & -2.12 \\
\hline April & 1.38 & 0.0555 & $* * *$ & 6.20 & 5.71 \\
\hline October & 1.23 & -0.0846 & $* * *$ & -13.52 & -8.12 \\
\hline $\mathrm{nb}$ of buyers & 2.24 & 0.0193 & $* *$ & 2.70 & 0.02 \\
\hline local daily supply & 2.79 & -0.1204 & $* * *$ & -20.61 & -0.12 \\
\hline national daily supply & 1.38 & $-1.2 \mathrm{e}-07$ & $* *$ & -3.10 & $-1.1 \mathrm{e}-04$ \\
\hline seller production $(\%)$ & 2.46 & -0.0226 & $* * *$ & -5.28 & -0.02 \\
\hline buyer purchase $(\%)$ & 3.20 & -0.0099 & $* *$ & -3.86 & -0.01 \\
\hline vessel length & 1.55 & 0.0423 & $*$ & 2.20 & 0.04 \\
\hline buyer dependence (year) & 1.58 & -0.0116 & $* *$ & -2.99 & -0.01 \\
\hline buyer type: fish merchant & 1.85 & -0.0342 & $* * *$ & -4.73 & -3.36 \\
\hline buyer type: transformer & 1.20 & -0.0424 & $* * *$ & -5.48 & -4.15 \\
\hline buyer importer & 1.99 & -0.0698 & $* * *$ & -9.90 & -6.74 \\
\hline seller loyalty rate (lot) & 3.04 & 0.0252 & $* * *$ & 7.73 & 0.03 \\
\hline buyer loyalty rate (vol) & 2.89 & -0.0163 & $* * *$ & -5.67 & -0.02 \\
\hline diligence rate $(\mathrm{S})$ & 1.82 & 0.0221 & $* * *$ & 5.04 & 0.02 \\
\hline $\mathrm{R}^{2}$ & & 0.3808 & & & \\
\hline
\end{tabular}

\begin{tabular}{|c|c|c|c|c|c|}
\hline \multicolumn{6}{|l|}{ Table B8. MA_8 (3606 obs.) } \\
\hline Variable & VIF & $\beta$ & & $t$-stat & ME \\
\hline cons & & 2.2348 & $* * *$ & 28.68 & \\
\hline auction & 1.08 & 0.0125 & $* *$ & 3.02 & 1.26 \\
\hline large size & 1.02 & 0.0173 & $* *$ & 3.12 & 1.74 \\
\hline April & 1.09 & 0.1566 & $* * *$ & 20.03 & 16.95 \\
\hline October & 1.17 & -0.1586 & $* * *$ & -22.28 & -14.66 \\
\hline December & 1.36 & 0.0471 & $* * *$ & 6.87 & 4.82 \\
\hline $\mathrm{nb}$ of buyers & 2.94 & 0.0075 & $* * *$ & 14.86 & $1.6 \mathrm{e}-03$ \\
\hline local daily supply & 3.76 & -0.1478 & $* * *$ & -17.67 & -0.15 \\
\hline national daily supply & 1.08 & -0.0081 & $* * *$ & -14.30 & -0.01 \\
\hline seller production $(\%)$ & 2.32 & 0.0080 & $*$ & 2.11 & 0.01 \\
\hline buyer purchase (\%) & 1.74 & -0.0171 & $* * *$ & -6.80 & -0.02 \\
\hline vessel length & 1.58 & 0.0582 & $* * *$ & 5.19 & 0.06 \\
\hline seller dependence (month) & 1.07 & -0.0257 & $* *$ & -2.89 & -0.03 \\
\hline buyer type: fishmonger & 1.49 & -0.0114 & $*$ & -2.34 & -1.13 \\
\hline buyer importer & 1.86 & -0.0296 & $* * *$ & -5.19 & -2.92 \\
\hline buyer exporter & 1.66 & 0.0178 & $* *$ & 3.46 & 1.79 \\
\hline seller loyalty rate (vol) & 1.63 & -0.0016 & $* *$ & -3.24 & $-8.3 e-05$ \\
\hline diligence rate $(\mathrm{B})$ & 1.65 & 0.0005 & $* * *$ & 4.13 & $2.4 \mathrm{e}-04$ \\
\hline $\mathrm{R}^{2}$ & & 0.5172 & & & \\
\hline
\end{tabular}

